\title{
WhiteNESS AND NARRATIVES OF A RACIALIZED CANADA-US BORDER AT NIAGARA ${ }^{1}$
}

\author{
JANE HeLleiner
}

\begin{abstract}
This paper analyses accounts of a racialized Canada/US border gathered from young white Canadian border residents. I argue that these accounts clearly support scholarly and activist reports of the "racial profiling" of nonwhites. While some white interviewees criticized the border practices that they described, some also suggested that nonwhites were appropriately targeted for greater surveillance as part of a binational security project. Meanwhile there was little acknowledgement of the significant benefits of whiteness in the racialized border context. While these white narratives contradict official denials of "racial profiling," I suggest that they ultimately offer limited challenge to racially differentiated border im/mobilities that reproduce racial inequality.
\end{abstract}

Key Words: border, Canada, US, whiteness, racism, mobilities

Résumé. Les entrevues avec de jeunes Canadiens blancs vivant en région frontalière incluaient des témoignages d'immobilisations à caractère raciste dans leur région frontalière. Tirés directement de l'observation et des témoignages d'autres personnes au sujet de passages à la frontière, ce qu'ils ont dit confirme en effet les travaux en cours sur le profilage racial d'organismes de sécurité. Alors que ces immobilisations à caractère racial étaient souvent considérées par les Blancs interviewés comme étant injustes et (ou) racistes, elles étaient également sanctionnées dans le cadre d'interprétations de Non-Blancs traversant la frontière; ils avaient effectivement été ciblés pour une plus grande surveillance dans le cadre d'un projet de sécurité binational. Les répondants ont certes constaté les conséquences de ne pas être Blanc pour traverser la frontière, ils n'ont cependant rien

1. This paper is based on interviews gathered as part of a larger project funded by the Social Sciences and Humanities Research Council of Canada Standard Research Grant \#410-2001-0894. I am indebted to Katie Sutton, Jessica Craig, Lindsey Foley, Cynthia Nyarko, Elizaveta Kozlova, Melissa St. Germaine-Small, Allison Burgess, Kieran Szuchewycz, Tomas Szuchwycz, Dr. Bohdan Szuchewycz, Dr. Anna Pratt, Dr. Amanda Glasbeek, and anonymous journal reviewers for assistance with the larger project and/ or this paper. Remaining weaknesses are my sole responsibility. Cynthia Nyarko's MA thesis titled: "Canada/U.S. Border Crossing: Facilitation and Constraint" (2004) analyzed some of the interviews discussed here. A version of this paper was presented at the November 2011 American Anthropological Association Meetings in Montreal.

(C) Canadian Journal of Sociology/Cahiers canadiens de sociologie 37(2) 2012 
dit sur le fait qu'il était généralement plus facile pour les Blancs de traverser la frontière et avoir accès à des débouchés et à une sécurité ontologique dans cette région. Ces histoires ont dérangé les interprétations officielles voulant que les frontières soient neutres sur le plan racial; d'ailleurs elles renforçaient souvent au lieu de remettre en question l'inégalité des immobilisations donnant lieu à des inégalités raciales.

Mots clés: frontière, Canada, E-U, blancheur, racisme, mobilité

\section{INTRODUCTION}

D) i/national and regional elites promote efficient and secure CanadaUS crossborder mobilities as a route to both continental and regional prosperity (Gilbert 2005; 2007; 2012). Elite promotion of, and investment in, secured mobilities, however, rarely acknowledges existing "modes of mobilized social inclusion/exclusion" (Sheller and Urry 2006:222). The way in which processes at border sites and border regimes facilitate mobilities for some, while delaying, intercepting, or otherwise immobilizing others has been a focus of comparative and critical border studies (Cunningham 2004; Cunningham and Heyman 2004). Some of this work has focused more specifically on racialized border im/mobilities and their relationship to the re/production of racialized inequality (e.g., Lugo 2000; Bejarano 2010; van Houtum 2010; Andrucki 2010).

This paper contributes to a growing scholarship that challenges still widespread constructions of a "friendly" Canada-US border, by drawing attention to historical and ongoing "unfriendly" realities of racialized border inclusions and exclusions (Bhandar 2008; see also Sharma 2006; Razack 2010; Pratt 2005; 2010; Pratt and Thompson 2008). The concept of racialization used in this literature and in this paper emphasizes how "racial signification is always and necessarily a social and historical process" (Winant 2004:155) that invokes biologized race and/or essentialized ethnicity, nationality, and/or religion in the context of relations and structures of subordination and/or privilege while being "an exercise of power in its own right" (Garner 2010:20). The term "racialization," in the context of an analysis of Canada-US border crossings, draws attention to how "racial" categories and identities are both constructed and contested within relations of power (as was apparent in the post 9/11 context), and linked to very real and unequal im/mobilities.

In this paper the analysis of interviews conducted with young white Canadian border residents reveals something of the dynamics of stratified cross border im/mobilities, and in particular, racially differentiated $\mathrm{im} /$ mobilities at one Canada-US border site. I argue that these white nar- 
ratives (drawn from direct observation and stories shared by others about border crossings), clearly support scholarly and activist reports of "racial profiling" and growing calls for the Canada Border Services Agency (which denies involvement in such practices), to be more accountable with regard to its adherence to civil and human rights (e.g., Canadian Human Rights Commission 2011).

My analysis also highlights that many white interviewees characterized racialized im/mobilities as "unfair" and/or "racist," but simultaneously legitimized these processes by describing nonwhite crossers as appropriately targeted by a larger binational security project. While these narratives disrupted official constructions of a nonraced border, they ultimately offered limited challenge to unequal im/mobilities that reproduce racial inequality.

The paper begins by contextualizing the study through reference to a history of racialized US-Canada and Niagara borders. It then looks at how white interviewees described (unnamed) white border crossings as internally differentiated before turning more fully to their accounts of racially differentiated border im/mobilities at Niagara. The paper concludes by addressing the relationship between the processes that they described and the unacknowledged benefits of mobilized whiteness.

\section{RACIALIZED BORDERS}

Canadian scholarship on racial profiling in policing and (to a lesser extent) border control has challenged the suggestion that this is a new phenomenon (Tator and Henry 2006; Tanovich 2006; Smith 2007). ${ }^{2}$ It is important to contextualize the present within longstanding exclusions and hierarchies originating in a white settler colonialism marked by "conquest, genocide, slavery and the exploitation of the labour of people of colour" (Razack 2002:2). Racialized border practices include a history of dispossession and constraints on crossborder mobilities experienced by indigenous populations (Hele 2008; Simpson 2008; Singleton 2009). As Grinde (2002:178) points out, the Canada-US border represents an imposition that continues to be contested by many First Nations: "as a symbol of their oppression by colonizing national governments that have sought to destroy and/or ignore their existence." At the same time, Canadian history has been marked by im/migration policies that favoured

2. Tanovich defines racial profiling in policing as "heightened scrutiny" "based solely or in part on race, ethnicity, Aboriginality, place of origin, ancestry, or religion or on stereotypes associated with any of these factors rather than on objectively reasonable grounds to suspect that the individual is implicated in criminal activity" (2006:13). For Canadian work see Wortley and Tanner 2005; Tanovich 2006; Tator and Henry 2006; Smith 2007; Satzewich and Shaffir 2009; Kitossa and Deliovsky 2010. 
white immigrants while admitting nonwhite migrants only in response to intense economic demand for labour and/or in ways that limited their citizenship rights. Despite the removal of explicit racial criteria from Canadian im/migration policies in the 1960s and the adoption of a policy of multiculturalism in the 1970s, an ongoing hegemonic white Canadian nationalism continues to obscure the long histories and contributions of populations of colour in Canada, positioning nonwhites as "negative disruptions of the Canadian landscape" (Peake and Ray 2001:180).

Bhandar (2008:291-2) comments that the "whiteness" of a constructed Canadian landscape extends to dominant constructions of a "white" Canada-US border (contrasted with the "white/brown" USMexico border), reinforcing normative white citizenship and locating nonwhites, regardless of citizenship, as outsiders in border space and as allegedly appropriate targets of heightened surveillance. Work on the contemporary Canada-US border demonstrates how the criminalization of nonwhites is now part of a broader crime-security nexus that invokes national security as a rationale for racially stratified crossborder im/mobilities (Pratt 2005; 2010; Pratt and Thompson 2008).

Razack (2010:89) references longstanding Canadian border processes that have reproduced a "racialized structure of citizenship in which people of colour, suspected of duplicity, must always be policed and kept at the margins of law and community" in her analysis of post 9/11 cases of Canadian official complicity in the rendition and torture of Canadian citizens of colour outside Canada and/or denial of their re-entry on the grounds of allegedly fraudulent identity. The ongoing costs of nonwhiteness in Canadian and other border spaces is evident in post 9/11 "no fly" and other government watch lists that have resulted in disproportionate refusals of entry, secondary screening, invasion of privacy, and traveller rights violations "for those from Muslim and Arab communities" (International Civil Liberties Monitoring Group 2010:52).

The November 2011 Canadian Human Rights Commission special report to Parliament notes that previous reports conducted for the United Nations as well as a Senate committee found that in Canada "members of many ethnic communities believe that they are singled out disproportionately by the staff of government security organizations... [and] that this amounts to racial or ethnic profiling" (Canadian Human Rights Commission 2011:8). This special report (which calls upon security agencies to produce verification of stated nonprofiling practices consistent with civil and human rights), highlights the issue of profiling at airports. While airports may be the primary border sites frequented by elites, however, Pratt and Thompson (2008) point out that the majority of those seeking entry (and re-entry) to Canada do so at land ports of entry. At these land 
ports of entry, moreover, there is less advance information on travellers available, resulting in greater reliance on informal (and as discussed below, often racialized) "discretion" on the part of border officers (Pratt and Thompson 2008:624).

This study was conducted in the Niagara border region, which is a leading North American tourist destination, a major corridor for continental trade, and a site of intense post 9/11 securitization. The Canada-US boundary line follows the Niagara River, running 55 kilometers from Lake Ontario to Lake Erie. The river is traversed by three railway (two currently functional) and four vehicle bridges. The latter are the Queenston-Lewiston bridge (linking the villages of Queenston, Ontario and Lewiston, New York), the Whirlpool and Rainbow bridges (connecting Niagara Falls, Ontario and Niagara Falls, New York), and the Peace Bridge (joining Fort Erie, Ontario and Buffalo, New York). During the period of data gathering for this study, the Peace Bridge was the second busiest Canada-US land border with 1.1 million trucks, 13.5 million vehicle and 1.4 million bus passengers crossing in 2005 and an estimated US\$75.4 billion in trade in 2006 (Regional Institute 2007).

The Niagara border region has a long history of racial diversity and struggles over racialized crossborder mobilities. The Canadian Niagara tourism industry has celebrated the role of the region as the terminus of the Underground Railway that offered refuge from slavery, but the region has its own history of slavery, forcible return of fugitive slaves to the US, and black segregation (Murray 2000; Cooper 2009). In a broader discussion of nationalized and diasporic blackness in Canada, Walcott (2003:32) notes that Fort Erie, Ontario hosted the 1905 meeting of the Niagara Movement that would later become the US National Association for the Advancement of Colored People. Niagara has also been a site of contested indigenous sovereignty and border crossing rights (Grinde 2002). ${ }^{3}$ By the 20th century, the region was a major entry point for Canada- and US-bound migrants whose movements were shaped by shifting and interconnected Canadian and US im/migrant, citizenship, and border regimes that facilitated and constrained crossings in racially differentiated and stratified ways.

In the contemporary era, the Canadian Niagara border was the site of a 1999 case of racial profiling taken to the Canadian Human Rights by Selwyn Pieters after his luggage was searched by a student Canada Customs inspector on a train at Fort Erie (Tanovich 2006:174). The settle-

3. Although the 1794 Jay Treaty "guaranteed the Iroquois the right to freely cross the Canada-US border without having to pay duties on trade goods" (Grinde 2002:168-9), indigenous border-crossing rights have long been a site of struggle at Niagara (Dirmeitis 2012). See also Dubinsky 1999:55-83 for the salience of race in the 19th and early 20th century tourist industry of Niagara Falls. 
ment of the case in 2002 involved "a ban on racial profiling at the border, a requirement that passengers be told why they are being selected for secondary inspection" as well as an agreement by Customs "to hire an expert to conduct anti-racism training... [and] to collect race-based data on who is selected for inspection" (Tanovich 2006:174-5). Any results of this agreement are not yet public and in the intervening period the renamed Canadian Border Services Agency has come under continued critique for racial profiling while continuing to deny the practice (Smith 2007:135-176; Pratt and Thompson 2008:620; Canadian Human Rights Commission 2011). The Niagara land border continues to be identified in reports as a site of racially stratified processes (e.g., for reference to a troubled re-entry for a Canadian of Middle Eastern origin at the Queenston-Lewiston bridge in 2008 see International Civil Liberties Monitoring Group 2010:18).

Pratt and Thompson's (2008:635) interviews with front line border officials at a major Canadian land port of entry in 2003-04 point to an "enabling ambiguity" inherent in official denials of racial profiling based on a "narrow definition of racial profiling as an explicit, formal directive from above to target members of a particular racial group." Their analysis reveals that whether such directives exist or not, a variety of personally and institutionally derived "racialized risk knowledges" shapes officers' self-reported discretionary treatment of border crossers based on attributed identities of race, nationality, ethnicity, culture, and religion. Official distinctions between "acceptable" profiling based on nationality, and "unacceptable" profiling based on race, were particularly significant as Pratt and Thompson report "when asked about racial profiling, officers commonly responded by talking about nationality" (2008:629). This slippage made possible border officials' acknowledgement of "legitimate" profiling of nationally identified nonwhites (including Canadian citizens) based on "reasonable suspicion" (Pratt and Thompson 2008; see also Pratt 2010).

To such work, this paper adds the narratives of young white border community residents with intimate knowledge of local border inspection processes. Many of those interviewed associated nonwhiteness with greater hassle at their local border in ways that parallel the claims of critics of racial profiling and the self-reported behaviour of the border officials analyzed by Pratt and Thompson (2008).

\section{The Study}

Much of the work on the functions and meanings of borders within an integrating North America grapples (supportively or critically) with 
the preoccupations and projects of economic and political elites (e.g., Nichol 2005; Salter 2007; Clarkson 2008). Comparative work among border residents and in border communities, however, reveals the value of eliciting the experiences and perspectives of those who have everyday knowledge of grounded border realities (Wilson and Donnan 1998; Donnan and Wilson 1999; Vila 2003). While most of the empirical work on racial profiling (appropriately) works to document and make visible the experiences of nonwhite populations who are consistently targeted, augmenting such studies with the observations of nontargeted whites can also contribute to this research.

The material analyzed here comes from a larger project that conducted 51 in-depth qualitative interviews from May 2001-August 2004 with a nonrandom convenience sample of Canadian border residents. The participants were recruited from a university-based population through announcements in first and second year undergraduate courses and through signs posted on a university campus. The interview questions focused on their experience of growing up in a border region. The interviews began in the months prior to $9 / 11$ but the shifting realities of border life in its aftermath meant that those interviewed post-9/11, invariably positioned their accounts of border life against a changing present of border securitization. The project was reworked to allow exploration of post-9/11 experiences and perceptions (for publications on other aspects of these interviews see Helleiner 2007; 2009a; 2009b; 2010).

For this paper I removed interviews conducted with 3 nonwhite interviewees and 9 older white respondents. The remaining set of 39 consisted of 22 female and 17 male white respondents born between 1976-1985. All of these individuals were university students at the time of the interviews: 17 grew up in Niagara Falls; 6 in Fort Erie; 8 in either Niagara-on-the-Lake, Queenston, or Chippawa; and 8 in Port Colborne, Welland, Thorold, Fenwick and St. Catharines, communities a little further away from the border. All were Canadian (and in some cases dual Canada-US) citizens. The interviews analyzed here are numbered as follows: 3, 5, 7-9, 11-13, 15-16, 18-19, 22, 24-29, 31-37, 39-51.

At the beginning of the interview, respondents were invited to discuss the education and occupation of family members and most offered details about their parents. A minority explicitly identified their class background and I have incorporated these self-identifications. For the remainder, I use reported parental education and occupation as an admittedly imperfect indication of class origin. Those described here as "upper middle class," for example, had at least one parent with university education and/or an occupation that required such a credential. Those described as "lower middle class" had at least one parent with some form 
of postsecondary education or training or occupation requiring such education or training. Those labelled as "working class" in this paper, had parents with partial college, high school or partial high school education and/or corresponding occupations. Overall then 10 of the 39 could be broadly described as upper middle class, 10 as lower middle class and 19 as working class.

While this small sample does not claim to be representative even of the regional age cohort (being skewed for example, by a universitybased recruitment strategy), the exploratory open-ended interviews allowed for interviewee-driven illumination of significant aspects of local border life, including racialized border crossings - a topic not highlighted in the original design of the study.

Consistent with studies of white identities, these 39 interviewees rarely self identified as white. As critical whiteness scholars point out, however, while "'whiteness' is apparently difficult for white people to name ... it nonetheless continuously shapes ... experiences, practices and views of the self and others" (Frankenberg 1993:228). For the purposes of this analysis "whiteness" was ascribed to interviewees based on a combination of their responses to an interview question about "cultural background," my own reading of their appearance, and/or self-identified contrasts with various forms of nonwhiteness.

Particularly useful for thinking about the experiences, practices, and views of whites in this border context is scholarship that emphasizes how "whiteness is constituted over time through a variety of material, cultural and spatial practices" (O'Connell 2010:537). The significance of spatiality was apparent in some interviewees' descriptions of a racial contrast between the whiteness of the Canadian side and relative blackness of the US side of the local border (Helleiner 2009a). This local construction of racialized border space contrasted with the hegemonic imagined "white" Canada-US border described by Bhandar (2008), but reproduced dominant constructions that equate Canadianness with whiteness by producing an "absented presence" (Walcott 2003; McKittrick 2007) of long standing indigenous, black, and other nonwhite communities in both Canadian Niagara and Canada as a whole. Here I focus on how, in the context of this racialized border geography, and wider national discussion of racial profiling (especially in the post $9 / 11$ period), young white Canadian border residents discussed the issue of racialized border crossings.

An interview schedule was provided to interviewees ahead of the interview, with questions about local border life that were then the basis of more unstructured conversations during the interview itself. A section on "border crossing" included questions about interviewees' childhood 
and contemporary crossings as well as those of others (see Appendix 1). Their responses drew upon personal experiences of local border dynamics (both as border crossers and in some cases border workers) as well as stories shared by friends, family, and/or border workers and local media reports.

Given the dynamics of in-depth qualitative interviews and the potentially sensitive topic of race, it is useful to note that 35 of the interviews analyzed here were conducted by the author, a white Canadian female professor. A black Ghanaian female graduate student conducted 3 (24, $25,26)$ and one was conducted by an Aboriginal female graduate student (39). These identities are highlighted here and noted in the analysis below because of the way they may have shaped interviewer/interviewee exchanges and silences on the topic of a racialized border.

The analysis first focused on locating all accounts of differentiated crossings in these narratives, and then identifying key themes within them, including those of race/racialization. The 24 (of 39) interviews that contained explicit references to race and/or racialized nationality, ethnicity, or religion, and the border were then examined more closely. Here it is important to note that while the interview schedule did not include an explicit reference to racialization, in 29 of the 39 interviews with white border residents, interviewees were specifically prompted by the interviewer to share any observations regarding the experiences of "visible minorities," "people of colour," or (less frequently) the possible role of skin colour or "race" in the context of questions about border crossings. Of the 29 who were prompted, 23 offered some related observations and/or commentary while 6 said they had little knowledge to draw upon or did not respond to this part of the question. (These 6 interviewees were numbered $13,15,34,41,42,47$, and those where the interviewer offered no explicit prompt were numbered 5, 7, 8, 9, 11, $16,22,29,39,43)$. In the 10 interviews where the interviewer did not explicitly prompt interviewees, one independently introduced the topic of First Nation border crossings (11). Including this with the others produced a total of 24 accounts of racialized border crossings that were then more closely examined to identify key themes.

Wortley and Tanner warn that the use of broad terms such as "visible minority" (or "nonwhite") in research on racial profiling "may in fact mask important racial differences in both experience and behavior and ultimately hinder the identification of racism in Canada" (2005:588). The "visible minority," "people of colour" phrasing of the prompts used in these interviews probably worked against eliciting additional white commentary about the crossborder mobilities of First Nations. Some of the interviewees who did not discuss a racialized border, included racial 
commentary when discussing other interview topics, e.g., alleged differences between the Canadian and US sides of the border, the composition of Niagara tourists and Canadian immigration policies.

\section{(Unnamed) Whiteness and Narratives of a Differentiated Border}

As Lewis points out, a great deal of research "engages whites in conversations about race only to ask them about their opinions about others ... [while] whites' own racial subjectivities, their very racialness, has not been given nearly the same amount of attention" (2004:624). While the bulk of the material used in this analysis relates to white narratives of the border crossings of nonwhites, I am also interested in illuminating (often indirectly) the significance of an (unnamed) normative whiteness for such crossings. I begin this by first focusing on how some of the border crossing stories offered by these interviewees, revealed how whiteness intersected with gender, age, locality, class, subcultural and/or ethnic identity, and demeanour to facilitate or trouble local cross border mobilities.

According to one working class female for example, "if you are a female going over you're pretty safe but if you're a male you'd be expected to be questioned and searched" (31). Elaborating on this theme of more constrained male mobilities, others indicated that this was particularly the case for younger men. Some young women's descriptions of navigating gendered and sexualized questioning by male border workers, however, pointed to the ways in which they too experienced border crossings shaped by gender and age.

Along with commentary about the ways that gender and age might shape crossborder mobility, some indicated that those living in the border region were more likely to have their passage eased while nonlocals were more likely to be selected for secondary inspection. Markers of lower class and/or counterhegemonic subcultural identities were also described as potentially producing slowed crossborder mobility. One young woman from Niagara Falls who described her class background as "low" but emerging into "middle class," described how crossings differed according to whether she was with her mother or her father. The latter's "rough exterior," she recalled, consistently attracted sustained questioning:

it was always relatively easy to go across with my mother ... we never had any hold ups. They'd just basically ask: 'where we were going, how long we were going to be there, when we will be returning?' and that was about it. When I crossed with my father on the other hand, he had a very 
rough exterior at that point in time ... the long shaggy hair ... into the late 1980s he was still dressing as a hippy. It just seemed to take forever to get across the border (22).

Markers of white ethnicity were also described as potentially triggering more intrusive questioning. For example, one lower middle class interviewee from Niagara Falls recounted how her Dutch-born father, a Canadian citizen who had been in Canada for over two decades, was regularly asked to produce his passport as proof of Canadian citizenship because of his "strong accent" (3). Another working class male described how Italian Canadian friends of his:

would always have to pull over and they would have to show something [travel documents]. And to me, that was weird because we [his family] never had that problem ... it was never a question of our citizenship or [that] we were in question as people (7).

Some interviewees recalled their parents making negative moralizing judgments about those observed to be experiencing delays. A young woman from an upper middle class background in Niagara Falls, recalled how her father might comment on those experiencing prolonged questioning or being pulled over for secondary inspection saying: "well look what they're driving, they look like troublemakers" (34). Another working class male recalled his father saying, "look at that guy, driving a beat up car, he's got long stringy hair, he kept his sunglasses on, he might have been smoking a cigarette, just a lot more suspicious" (46). While the first interviewee was uncomfortable with the assumption that simple appearance could mark a "troublemaker," such commentary about allegedly predictable markers of "trouble" and "suspicion" reveal how white border residents re/produced hierarchies of more or less desirable or respectable (unnamed white) crossers who were legitimately facilitated and/or constrained at the border. Interviewees also reported receiving parental coaching on how to avoid hassle at the border being quiet, keeping hands on laps, removing sunglasses and hats, not "joking around" or being a "smart ass." Socialization into border "performances" that successfully communicated inherent respectability to border officials was credited by some with easing crossborder passage.

\section{Whiteness and Narratives of A Racialized Border}

The influence of unnamed whiteness on the above descriptions of crossborder mobilities shaped by gender, age, locality, class, ethnicity, and demeanour became clearer when white interviewees made explicit refer- 
ence to what they generally acknowledged to be more significant constraints on crossborder mobility associated with officially identified nonwhite identities. Within the local context, much of the white commentary about "race" consisted of stories about the crossings of African Americans and for the later post 9/11 period, those identified by interviewees as Muslim, Arab, and/or East Indian. While the white interviewees' accounts suggested how these identities also intersected with other markers, such as those of age, gender, and class, interviewees portrayed the racialized identities as primary determinants of more surveilled crossings.

As mentioned above, however, not everyone commented on a racialized border even when directly prompted. One young working class woman from Niagara-on-the-Lake for example, claimed to the white interviewer, that her knowledge was limited because "nobody really in Niagara is ... of a different origin or whatever. Like it's not your friends that are" (15). This response to a prompt about the border crossing experiences of "visible minorities" erased nonwhite populations from the region and then (in an apparent reconsideration) from sociality. The female respondent quoted earlier describing her fathers "rough exterior," volunteered that as a child she was unaware of the significance of race in cross border mobilities because she had gone to school with "largely white middle class families. There wasn't a great diversity at all so I didn't really have the opportunity to be exposed to other perspectives and opinions and experiences" (22).

Many however, had a fair bit to say about how race mattered for nonwhite Canadian and US citizens trying to cross the border both pre and post $9 / 11$. This was made clear even when explicit race-talk was avoided or involved hesitant responses as in the following exchange between a working class female from Thorold and the Ghanaian interviewer about people who experienced greater hassle at the border.

Respondent: ... I know some people, if they look suspicious, so obviously ... [border officials] would be suspicious of them, which is not always right, but it is for safety reasons so ...

Interviewer: So you talk of 'being suspicious,' in what way would someone be seen as 'being suspicious'?

Respondent: Well, I know, like a few people, I know it is racist and I don't believe in this, but you know, a lot of people, their colour, because they have a different colour right? I find that. I really don't know ... [border officials] think they [people of colour] are violent. Like people at the border. Because I remember, I had a friend growing up and she is coloured 
right? And sometimes she'd, like they'd stop her and they'd be asking her all these questions. And they won't ask me all the same questions, which I find wrong but like, for some reason, they link those [being "coloured" and violence]. I don't know (26).

In this exchange the interviewee suggests that those who "look suspicious" might be stopped "for safety reasons" and when asked to elaborate on this, links "looking suspicious" with being "a different colour" - a linkage that is identified as "racist." She goes on to describe the prolonged questioning of a "coloured" friend as "wrong," but the fractured narrative communicates discomfort with being prodded on the topic. The invocation of the "coloured friend" and repeated claims of ignorance may have been introduced to assert an (unnamed) "white self innocent of racism" (Frankenberg 1993:188)

Others were more explicit in their discussion of race at the border. One young man, from a working class family in Queenston, for example, described to the white interviewer how one time he and some friends were "pulled over" [to secondary inspection] and how he was pretty sure that the US border officials were looking for drugs and that the car was targeted because one of his friends was "mulatto." He concluded this he said, because: "there wasn't really anything out of whack with anyone else ... [so] race hit us right away" (51). In this story uncriminalized whiteness was the unspoken norm which made the "mulatto" friend "out of whack" and "race" salient to him and his white friends who responded by attributing the unusual experience of heightened surveillance to a criminalization of blackness.

The significance of blackness was emphasized by another young woman from a working class background in Niagara Falls who told the white interviewer a story about the experience of a friends' AfricanAmerican boyfriend who got "pulled in" to secondary inspection by Canadian officials who called her friend's house and asked her father: "do you know that this guy is coming to your house?" She felt that this illustrated how border crossing into Canada: "really has a lot to do with your ethnic background, like if you're not white then they lay it into you which I don't think is very fair" adding: "I mean he's in university, he's a good kid, he works, he loves his parents ... but because he's black he got pulled right in" (40). ${ }^{4}$

4. Though not acknowledged by the narrators or pursued by the interviewers, these accounts hint at how surveillance of young African American men may intersect with the sexual regulation of young white females through the targeting of "interracial" heterosexual couples in a border context of extensive crossnational relationships (see Deliovsky 2010 and Kitossa and Deliovsky 2010 for a discussion of racial profiling and "compulsory white female heterosexuality" in the Canadian context). 
These narratives point to how interracial friendships could heighten white interviewees awareness (and often critique) of racially differentiated treatment at the border. In addition, they referenced knowledge derived through direct or indirect links to those employed at the border. One lower middle class interviewee, describing how border workers could reproduce "negative stereotypes," distanced himself from their content when he reported to the white interviewer how:

One guy in my [university] class, he's a customs officer, and pretty much all of the negative stereotypes ... about different races crossing [the border], he was pretty much reinforcing ... I don't really want to say the stuff he was saying just because it is kind of offensive (37).

Another female respondent with a working class background, told the white interviewer how she had learned from a friend working at the border about

the stereotypes that they [the Canadian border officials] ... follow. That they're like ...you see two young guys in a car, you see one black guy and some are white or you see two black guys in a nice car and they will pull them over, like most definitely. (18)

This interviewee went on to describe waiting in line to re-enter Canada with this friend and how

she picked off every car [that was experiencing a delay at the Canadian border] and she explained to me why. And it was all stereotypes. Like she just looked at them and she knew [that they would be delayed]. (18)

Similar to the previous young man and many other respondents, this interviewee used the language of "stereotypes" to signal distance from, and a degree of critique of, the racially differentiating processes that she was reporting. Likewise a young woman from Fort Erie, also working class, who had worked at the bridge in a custodial capacity commented to the white interviewer:

This is very stereotypical and racial but if there was a car of black Americans that was overfilled that would be turned away [by Canadian border officials] ... we [other border workers] used to be able to ... pick out who was getting pulled over. (19)

While this commentary is apparently critical of over policing based on "stereotypes," when asked to elaborate, the latter interviewee linked the intercepting of African-Americans at the Canadian border, to their allegedly more tenuous citizenship revealing a racialized hierarchy of citizenship at work: 
Interviewer: So you mentioned black Americans and the way people would look so I am assuming that skin colour was kind of a major marker [for hassle at the border]

Respondent: Yeah, just because you could tell they're not native American [or] Canadian so.... (19)

Here the white interviewer is made complicit in the presumption that border control "can tell" that African Americans are not in fact, fully "native" American (and African-Canadians not fully Canadian), and therefore allegedly reasonably subject to greater scrutiny. Blackness was equated with less than full citizenship that justified greater surveillance.

\section{Whiteness and Post 9/11 Border Securitization}

Interviewees drew upon personal observations and the reports of friends, family, acquaintances, and the media to describe what they believed to be a deeper and expanded racially stratified border in the post 9/11 period as surveillance of blackness widened to include an intensified focus on other (variously identified) nonwhites. Again border workers were an important source of knowledge about post 9/11 developments. One upper middle (but self-described "middle") class female from Welland, reported that an acquaintance working at the border had told her that: "basically anyone with colour is going to be questioned in depth ... especially if they look of Middle Eastern descent" (36). Another working class male from Niagara Falls claimed

I ... knew from my friends who worked at the border that if you happen to be Arab you'd have a hard ... time going through ... we deliberately didn't cross the border [with a Turkish friend] because it was right after September 11th and I knew they'd [border officials] give him a huge hassle. (28)

Another female from a lower middle class family in Welland commented: "anybody East Indian, or that looks it, they pull over regardless" (32). Describing a crossing into the US over a year after September 11, 2001, a young working class male from Niagara Falls respondent recounted to the white interviewer how:

When we got close to the actual [US] border ... there was a customs officer walking down the aisle between the cars looking in everyone's car. He passed our car, but I did see [in the case of] any coloured people [or] someone wearing a religious headdress, he would stop at their window and ask them questions (33). 
While many interviewees described the costs of officially perceived nonwhiteness at the local border, their narratives were silent on how their own and others whiteness produced more facilitated crossings in this context. Eased crossings were more likely to be attributed to the successful performance of what was felt to be an inherently individual "desirability" rather than structured white privilege.

Threatened loss of racialized privilege, however, emerged indirectly in stories from two interviewees who described how intensified surveillance of those with darker skin in the post 9/11 era made them more vulnerable at the border. The young woman quoted above saying that even those who just looked "East Indian" would be targeted, for example, told of taking her parents across the border to the Buffalo airport, and how US officials asked for her driver's license. In her license photo she reported: "I'm really tanned and they asked if I was really Canadian. So I don't know if that's why they asked, but it was weird" (32). While not certain that her tanned skin had led to the questioning of her "Canadianness," she presented this as a plausible explanation for the otherwise "weird" situation of having her citizenship questioned as a (clearly self identified but still unnamed) white crosser. The story reveals awareness of the contingency of whiteness - and the cost of nonwhiteness, i.e., eviction from a self-evident "Canadianness" that would produce new constraints on cross border mobility.

Anxiety about being racially misread was even clearer in the account of a lower middle class male from Fort Erie who in a discussion of post 9/11 changes in border inspections, suggested that "If you're Italian having olive coloured skin and can grow a thick beard, I've seen cases where they'll think you're an Arab ... even if you're not even close" (35). That this was a more personalized concern was made clearer when he added the observation that:

even if you look like you might be Muslim, now my own appearance, I mean, I'm obviously not, but I've got dark hair, a beard, somewhat of a darker, you know, tanned complexion ... so if I go over that border, I could have a problem, even though ... I don't look Muslim, but that remote chance, I mean, you could get interrogated (35).

Here the presumed consequence of being officially racialized as "Muslim" by virtue of a "darker" complexion, is a loss of whiteness and a resulting increased risk of "interrogation." 


\section{Critique and Legitimation of a RaCialized Border}

As indicated, these white interviewee accounts of racialized stratification often included critical commentary that labeled such processes as "unfair," and driven by "stereotypes" and/or "racist" particularly when these affected friends and acquaintances. Sometimes this critique took on an anti-American flavour in focusing on US officials mistreating fellow Canadian citizens. The respondent who had critiqued Canadian border authorities for their treatment of her friend's African-American boyfriend, was also critical of US officials' treatment of a Palestinian Canadian friend-of-a-friend. She reported that:

even though he was born in Canada [and] is a Canadian citizen ... they [US border officials] were just so mean to him because of his background that they [her friends] didn't think they were going to get over the border. So they [the border officials] just searched the car up and down ... and then they sent them on their way, but he [the Palestinian Canadian] was like 'sorry guys, you know, like, my parents were born there,' and they [the border officials] take it out on him. (40)

The focus on an allegedly nationalized American "meanness" here deflects attention from the structurally similar discriminatory behaviour reported earlier for Canadian border authorities.

Another upper middle class male respondent from Niagara Falls went beyond a defense of friends or friends-of-friends, to offer a broader critique of US border officials' behaviour toward fellow Canadians to the white interviewer:

I remember seeing on TV once, this story about four young men that were of Middle Eastern descent, and they were Canadian, and they were just going over the border [to the US] ... and they ended up being stopped and put into a cell for four hours ... that really ticked me off because they're Canadians. (44)

The panracial Canadianness invoked here went beyond personalized outrage at the treatment of friends to challenge broader equations of Canadianness with whiteness. Deflections of blame for a racially unequal border to the US side, however, worked against greater troubling of similar processes on the Canadian side and fed easily into longstanding dominant claims of Canadian racial progressiveness or even racelessness relative to the US (Tanovich 2006:504; Bhandar 2008).

More significantly however, along with critique white interviewees also often offered (sometimes simultaneous) support for the racialized processes that they described on the grounds that they were necessary 
for binational security. The interviewee who had worried that her tan had resulted in a questioning of her Canadian citizenship for example, described US border practices as "discriminatory" but nonetheless legitimate given post 9/11 US concern that Canada was a source of terrorists:

there's definitely that discrimination, but at the same time, I think they [US border officials] kind of had to, because I guess Canada was their main concern at that time, and even though it was maybe a little discriminatory, I think they had to do it that way. (32)

Another young man from a family of "blue collar workers" in Niagara Falls also labeled US actions as "unfair" but told the white interviewer that they were justified when he commented on how:

American customs has really been cracking down on anyone that really isn't Caucasian. Which I guess I can understand to a degree because of the problem with the terrorists ... but it's kind of not fair because just because you look a certain way doesn't mean you have ... [a terrorist] belief system ... you have to check those people, but it's not fair because not everyone's a bad person, just because you're of a certain nationality. (48)

Here the racialized category of "non-Caucasian" slips into those of a "certain nationality." The "race-evasive" language of "nationality" then positions nonwhites as less-than-full Canadians or Americans who can be legitimately profiled. This latter respondent also drew a parallel between racialized antiterrorist "cracking down" and more routine cases where the racial profile of an escaped criminal would lead border officials to be reasonably "scrutinizing everybody of that nationality." Of this latter kind of targeting (and by extension the more general antiterrorist measures), he suggested: "it's not fair but it's just a security thing" (48).

A respondent from Port Colborne discussing the immediate post 9/11 period with the white interviewer stated that "things have changed and they are increasing security. Unfortunately some of it is ethnic and the ways they identify suspects is racial profiling" (27). This upper middle class individual added that "people are just experiencing more prejudice now. That is becoming a fact of life that people have to deal with." Here explicitly named "racial profiling" based on "prejudice" is justified on the grounds that "if you weren't a criminal and you didn't have any reasons... to... hide then it shouldn't be a problem" (27). Likewise the interviewee who was quoted earlier describing how her "coloured friend" was subjected to more questioning than herself, something she had described as "wrong" also claimed that she hadn't: "heard ... many stories of innocent people ... having a problem at the border" (26). While 
an interracial friendship had provided this white respondent with insight into the existence of a racially differentiated border, the cost for this friend was downplayed in the suggestion that few "innocent" people experienced border "problems." Nonwhites, clearly acknowledged by many of these interviewees to have more difficult border crossings, could, through this circular logic, be understood as less "innocent" as a result of this same difficulty. These statements then reveal how recognition, and in some cases, partial critique of racial profiling, could coexist with legitimation of the resulting violation of civil and human rights of nonwhites, even "friends."

Attempts to reconcile critique and legitimation of racially unequal inspections were apparent in efforts to distinguish between acceptable "criminal profiling" and "racist" behaviour on the part of border officials. The Welland interviewee who thought that her tan may have prompted questioning about her citizenship, used such a logic describingf how: "African-Americans" driving a "nice car" got "pulled over a lot more than a white person would" when entering Canada (32). She suggested that this practice was security driven because while: "a lot of times ... [the border guard] could be wrong ... that one time that they're right [they] could save someone maybe" (32). When asked by the white interviewer to clarify how the possibility of "saving somebody" made such racial targeting legitimate, the interviewee first appeared critical of racial profiling but then invoked the motivation of the Canadian guard as central to determining whether the action was "racist" or not:

Maybe so not much an African-American driving a nice car. I mean, it shouldn't just make up ... [border officials] mind like that. They should still question them or whatever. But I guess it depends on the person. If [border officials] are doing it to protect the country, then it is one thing, but if they're doing it because they're racist, then I think it's totally wrong.

This interviewee asserted that racism was wrong, but separated racism from Canadian border officials' practice of stopping AfricanAmericans in "nice cars" which, it was suggested, might be done to "protect the country." What might otherwise be deemed "racist" and therefore "wrong," is justified by a security rationale and therefore not racist. The determining factor as to whether such selective stopping was racist or not was allegedly the (externally inaccessible) interior motivation of the border worker.

Razack (2009:819) writes of the importance of "following the colour line behind security discourses, [of] tracking the racial logic that divides humanity into those who are threats and those who must be protected." 
While some young white border residents critiqued the border practices that they discussed, they could also reproduce the racist logic of security discourses that made nonwhite crossers as a collective, suspicious and potentially threatening to a presumptively white "country" and "people" whose "protection" required a racially stratified border. In doing so, they drew upon and reproduced discourses of racialized citizenship, criminalization, and securitization (Tator and Henry 2006:201) that insecuritize nonwhite communities by threatening their "physical and psychological integrity and dignity" (Tanovich 2006:171), through civil and human rights violations (Ontario Human Rights Commission 2005; Canadian Human Rights Commission 2011).

\section{Whiteness at a Racialized Border}

The inverse of the heightened surveillance of nonwhites at the border is what Du Bois termed the "wages of whiteness" derived from "privileged status in the eyes of authority" (Winant 2004:62). In this border region, it is clear that officially perceived whiteness provided significant material and ontological rewards. Elsewhere I have outlined how those interviewed had long histories of accessing crossborder shopping, cheaper air travel, and other recreational educational and employment options beneficial to everyday social reproduction in a deindustrializing border economy. Similar to other borderland regions (see Van Schendel 2005) moreover, such crossborder mobilities included acknowledged practices of minor smuggling facilitated by a untroubled citizenship and noncriminalized status (Helleiner 2007; 2009a). ${ }^{5}$ Eased crossborder movement then permitted greater access to both authorized and unauthorized economic opportunities at this major node of an integrated North American and global economy producing structurally derived "whiteness-asmateriality" (Andrucki 2010:360), as well as sense of desirability as a binational citizen that played into a whiteness-as-ontological-security.

Such privileges of whiteness, however, emerged only indirectly in interview narratives, for example, in the context of expressed concern that post $9 / 11$ security might be marked by more universal (e.g., less discretionary) processes. Indeed some of these interviewees were angered by the possibility of being subjected to some of the same constraints (e.g., longer lines, more prolonged questioning, and requests to produce

5. That those officially perceived as white benefit from the "discretion" employed by border officers over more universalized border practices, is suggested by Pratt's reference to the claim of one senior manager with the Canada Border Services Agency that "statistically generated randomized searches" generated "more 'hits' (searches that result in a seizure)" than "case-by-case risk assessments by border officers" (Pratt 2010:470). 
new documents) that they recognized had long been experienced by nonwhites. Several described reducing their discretionary border crossings in response to this possibility (Helleiner 2010).

A male from an "upper middle class area" in Niagara Falls shared his frustration with an anticipated loss of eased crossings due to increased US security in particular:

It makes me kind of angry. That's fine for security but, I don't know, it's just I feel like, 'hey, I grew up here and I've come across your border and I know I'm not meaning any harm and I'm going to give your economy money [through crossborder shopping] and you're giving me such a hard time to get across' ... I don't like going there anymore. I just want to get out as fast as I can. (49)

Likewise the interviewee who criticized Canadian border enforcement's treatment of her friend's African-American boyfriend complained that in the post $9 / 11$ period:

Everything started to get really harsh. The Americans are brutal at the border and they just look you up and down and they want to know everything about you and where you were? And how much you spent? And why you were there? And why you couldn't buy that in your own country? And why do you have to come here? (40)

While her description of the treatment of her friend's African-American boyfriend at the Canadian border, made it clear that she was aware that things had been "harsh" for nonwhites for some time and that this was true of the Canadian as well as US border, she nonetheless was frustrated at the perceived loss of her own (unnamed) racial privilege, and expressed her desire for a new form of visibility, "a sign," that would ensure continued facilitated mobility:

I just want to wear a sign that says like I have no drugs, I have no weapons, I go to university ... I'm not a bad person, you can trust me, I've had a job for five years ... the same one ... I should have a list across my shirt that just says OK, I'm clean ... let me go through! (40)

Despite such white concerns about the possibility of more universally applied border security, however, there is little evidence of a move toward processes that would subject all crossers to similar processes. Evidence regarding the Canada-US border in the post $9 / 11$ period (as with many other border regimes globally), suggests that on the contrary, border processes have become more rather then less stratified - and that this stratification is deeply racialized as nonwhites face greater risks of sustained and/or intrusive interrogation, physical searches, arrests as 
well as more dramatic detention, life threatening deportation and/or rendition (Razack 2010; Van Houtum 2010; International Civil Liberties Monitoring Group 2010). The result has been a further entrenchment of the material and ontological benefits of whiteness as a globalized "passport of privilege" (Andrucki 2010:360).

\section{Conclusion}

Elite binational and regional voices promote an intensification of secured Canada-US crossborder mobilities as the route to prosperity. Their vision invokes a raceless border crosser who works to maximize the opportunities of continental (and global) mobility. Calls to border residents and other Canadians to grasp the much touted alleged opportunities of an binational Niagara and North America, do not acknowledge what is recognized by many of these young white border residents, notably that the local border is marked by racially stratified im/mobilities that contradict official denials of racial profiling. While some of these interviewees criticized the racialized border processes that they described, however, such critique could be combined with suggestions that nonwhites were inherently "suspicious" in border space and therefore appropriately targeted for greater surveillance as part of a binational security project. For these white interviewees moreover, such processes provided an unearned and unnamed preferential access to crossborder opportunities even while they recognized that nonwhites faced greater risk of state sanctioned violence. This reveals how local white knowledge and even critique of racial profiling, may coexist with tacit or explicit support for such practices (rather than antiracist sentiment or action). Elite projects predicated on increasing secured crossborder mobilities that reinscribe existing mobilized inclusions/exclusions threaten to further entrench racialized inequalities. The narratives of the young white border residents analyzed here, while illuminating the phenomenon of a racially stratified border offer only limited challenge to these processes and outcomes.

\section{REFERENCES}

Andrucki, Max. 2010. The visa whiteness machine: Transnational motility in post-apartheid South Africa. Ethnicities 10(3):358-370.

Bejarano, Cynthia. 2010. Border rootedness as transformative resistance: Youth overcoming violence and inspection in a US-Mexico border region. Children's Geographies 8(4):391-399. 
Bhandar, Davina. 2008. Resistance, detainment, asylum: The onto-political limits of border crossing in North America. Pp. 281-302 in D. Cowen and E. Gilbert, eds., War, Citizenship, Territory. New York: Routledge.

Canadian Human Rights Commission. 2011. Human Rights Accountability in National Security Practices: A Special Report to Parliament. Ottawa.

Clarkson, Stephen. 2008. Does North America Exist? Governing the Continent After NAFTA and 9/11. Toronto: University of Toronto Press.

Cooper, Afua. 2009. Acts of resistance: Black men and women engage slavery in Upper Canada 1793-1803. Pp. 239-249 in M. Wallis and A. Fleras, eds., The Politics of Race in Canada. Don Mills: Oxford University Press.

Cunningham, Hilary. 2004. Nations rebound? Crossing borders in a gated globe. Identities: Global Studies in Culture and Power 11(3):329-350.

Cunningham, Hilary and Josiah McC. Heyman. 2004. Introduction: Mobilities and enclosures at borders. Identities: Global Studies in Culture and Power 11(3):289-302.

Deliovsky, Katerina. 2010. White Femininity: Race, Gender and Power. Halifax: Fernwood.

Dirmeitis, Mary 2012 For Decades, The Haudenosaunee Have Protested a Border They Didn't Draw. This Magazine January 26. http://this.org/ magazine/2012/01/26/for-decades-the-haudenosaunee-have-protested-aborder-they-didn't-draw/ [accessed February 18, 2012]

Dubinsky, Karen. 1999. The Second Greatest Disappointment: Honeymooning and Tourism at Niagara Falls. Toronto: Between the Lines.

Donnan, Hastings and Thomas Wilson. 1999. Borders: Frontiers of Identity, Nation and State. Oxford: Berg.

Frankenberg, Ruth. 1993. White Women, Race Matters: The Social Construction of Whiteness. Minneapolis: University of Minnesota Press.

Garner, Steve. 2010. Racisms: An Introduction. Los Angeles: Sage.

Gilbert, Emily. 2005. The inevitability of integration? Neoliberal discourse and the proposals for a new North American economic space after September 11. Annals of the Association of American Geographers 95(1):202-222. 2007 Leaky borders and solid citizens: Governing security, prosperity and quality of life in a North American partnership. Antipode 39(1):7798.

2012 Harper's Border Deal Expands the National Security State. Rabble. ca. February 1. http://rabble.ca/news/2012/02/harpers-border-deal-expands-national-security-state. [accessed February 18, 2012]

Grinde, Donald A. (Yamasee) 2002. Iroquois border crossings: Place, politics, and the Jay Treaty. Pp. 167-180 in C. Sadowski-Smith, ed., Globalization on the Line: Culture, Capital, and Citizenship at U.S. Borders. New York: Palgrave. 
Hele, Karl, ed. 2008. Lines Drawn Upon the Water: The First Nations Experience in the Great Lakes Borderlands. Waterloo: Wilfrid Laurier Press.

Helleiner, Jane. 2010. Canadian border resident experience of the "smartening" border at Niagara. Journal of Borderlands Studies. 25(3\&4):87-103. 2009a. "As much American as a Canadian can be": Cross-border experience and regional identity among young borderlanders in Canadian Niagara. Anthropologica 51(1):225-238.

2009b Young borderlanders, Tourism work and anti-Americanism in Canadian Niagara. Identities: Global Studies in Culture and Power. 16(4):438-62.

2007 "Over the river": Border childhoods and border crossings At Niagara. Childhood: A Global Journal of Child Research. 14(4):431-447.

International Civil Liberties Monitoring Group. 2010. Report of the Information Clearinghouse on Border Controls and Infringements to Travellers' Rights. $\quad$ http://www.travelwatchlist.ca/updir/travelwatchlist/ICLMG Watchlists_Report.pdf (Accessed December 5, 2011).

Kitossa, Tamari and Katerina Deliovsky. 2010. Interracial unions with white partners and racial profiling: Experiences and perspectives. International Journal of Criminology and Sociological Theory 3(2):512-30.

Lewis, Amanda. 2004. "What group?" Studying whites and whiteness in the era of "color-blindness." Sociological Theory 22(4):623-646.

Lugo, Alejandro. 2000. Theorizing border inspections. Cultural Dynamics 12(3):353-373.

McKittrick, Katherine. 2007. "Freedom is a secret." Pp. 97-114 in K. McKittrick and C. Woods, eds., Black Geographies and the Politics of Place. Cambridge, MA: South End Press.

Murray, David. 2000. Hands across the border: The abortive extradition of Solomon Moseby. Canadian Review of American Studies 30(2):187-210.

Nichol, Heather. 2005. Resiliency or change? The contemporary Canada-US border. Geopolitics 10:767-790.

O'Connell, Anne. 2010. An exploration of redneck whiteness in multicultural Canada. Social Politics 17(4):536-563.

Ontario Human Rights Commission. 2005. Paying the Price: The Human Cost of Racial Profiling. Ottawa.

Peake, Linda and Brian Ray. 2001. Racializing the Canadian landscape: Whiteness, uneven geographies and social justice. Canadian Geographer 45(1):180-186.

Pratt, Anna. 2005. Securing Borders. Vancouver: University of British Columbia Press.

2010. Between a hunch and a hard place: Making suspicion reasonable at the Canadian border. Social and Legal Studies 19(4):461-480. 
Pratt, Anna and Sara Thompson. 2008. Chivalry, 'race' and discretion at the Canadian border. British Journal of Criminology 48(5):620-640.

Razack, Sherene. 2002. When race becomes place. Pp. 1-20 in S. Razack, ed., Race, Space, and the Law: Unmapping a White Settler Society. Toronto: Between the Lines.

2009. Afterword: Race, desire, and contemporary security discourses. University of Toronto Quarterly 78(2):815-20.

2010. Abandonment and the dance of race and bureaucracy in spaces of exception. Pp. 87-107 in S. Razack, M. Smith and S. Thobani, eds., States of Race: Critical Race Feminism for the 21st Century. Toronto: Between The Lines.

Regional Institute. 2007. Defining the Region's Edge. Buffalo: University at Buffalo Regional Institute. http://www.regional-institute.buffalo.edu/ Includes/U.S.erDownloads/RegionsEdge 6 07.pdf (Accessed December 5, 2011)

Satzewich, Vic and William Shaffir. 2009. Racism versus professionalism: Claims and counter-claims about racial profiling. Canadian Journal of Criminology and Criminal Justice 51(2):199-226

Salter, Mark. 2007. Canadian post-9/11 border policy and spillover securitization: Smart, safe, and sovereign? Pp. 299-319 in M. Orsini and M. Smith, eds., Critical Policy Studies. Vancouver: University of British Columbia Press.

Sharma, Nandita. 2006. White nationalism, illegality and imperialism: Border controls as ideology. Pp. 121-143 in K. Hunt and K. Rygiel, eds., (En) Gendering the War on Terror: War Stories and Camouflaged Politics. Aldershot: Ashgate.

Sheller, Mimi and John Urry. 2006. The new mobilities paradigm. Environment and Planning $A$ 38(2):207-226.

Simpson, Audra. 2008. Subjects of sovereignty: Indigeneity, the revenue rule, and juridics of failed consent. Law and Contemporary Problems 71(3):191-215.

Singleton, Sara. 2009. Not Our Borders: Indigenous People and the Struggle to Maintain Shared Lives and Cultures in post 9/11 North America. Working Paper No. 4. Bellingham: Border Policy Research Institute Western Washington University.

Smith, Charles. 2007. Conflict, Crisis, and Accountability: Racial Profiling and Law Enforcement in Canada. Ottawa: Canadian Centre for Policy Alternatives.

Tanovich, David. 2006. The Colour of Justice: Policing Race in Canada. Toronto: Irwin law.

Tator, Carol and Frances Henry. 2006. Racial Profiling in Canada: Challenging the Myth of 'A Few Bad Apples'. Toronto: University of Toronto Press. 
Van Houtum, Henk. 2010. Human blacklisting: The global apartheid of the EU's external border regime. Environment and Planning D: Society and Space 28(6):957-976.

Van Schendel,Willem. 2005. Spaces of engagement: How borderlands, illegal flows, and territorial states interlock. Pp. 38-68 in W. van Schendel and I. Abraham, eds., Illicit Flows and Criminal Things: States, Borders and the Other Side of Globalization. Bloomington: Indiana University Press.

Vila, Pablo, ed. 2003. Ethnography at the Border. Minneapolis: University of Minnesota Press

Walcott, Rinaldo. 2003. Black Like Who? Writing Black Canada. Toronto: Insomniac Press. Second Revised Edition.

Wilson, Thomas and Hastings Donnan, eds. 1998. Border Identities: Nation and State as International Frontiers. Cambridge: Cambridge University Press.

Winant, Howard. 2004. The New Politics of Race: Globalism, Difference, Justice. Minneapolis: University of Minnesota Press.

Wortley, Scott and Julian Tanner. 2005. Inflammatory rhetoric? Baseless accusations? A response to Gabor's critique of racial profiling research in Canada. Canadian Journal of Criminology and Criminal Justice 47(3):581609. 


\section{Appendix 1}

Questions about border crossings included in the interview schedule were as follows:

1. How often and with whom did you cross the border at Niagara as a younger child?

2. Did this change as you got older?

3. What were some of the reasons that you crossed the border e.g. shopping, visiting friends/family, tourism, recreation etc?

4. Did the reasons change as you got older?

5. What happened as you crossed the border e.g. experiences with border officials?

6. Did these change as you got older?

7. What did it feel like to cross the border when you left Canada and when you came back to Canada?

8. Can you provide any stories about particular crossings that you can still remember?

9. Do you think that your experiences of border crossing were similar or different to those of other kids/families that you knew?

10. Why did other kids/families cross the border?

11. What stories do you recall hearing from other children about this experience?

12. As a child were you aware that some people might have problems crossing the border e.g. friends and neighbours, tourists, immigrants, refugees?

13. As a child were you aware of the risks that some people took in border crossing e.g. being turned back, arrested, deported, injured or killed in the crossing process?

14. What factors do you think make it easy or difficult for people to cross today?

Jane Helleiner is a Professor in the Department of Sociology at Brock University in St. Catharines, Ontario. She is author of the monograph Irish Travellers: Racism and the Politics of Culture and numerous articles. 
